DOI: $10.15642 / J I I S .2014 .8 .1 .23-38$

\title{
THE ROLE OF CHENG HO MOSQUE The New Silk Road, Indonesia-China Relations in Islamic Cultural Identity
}

\author{
Choirul Mahfud \\ Institute for Religions and Social Studies, Surabaya - Indonesia | mahfudjatim@yahoo.com
}

\begin{abstract}
This article discusses the role of the Cheng Ho mosque in developing cultural, social, educational and religious aspects between the Chinese and non-Chinese in Indonesia and in strengthening the best relationship internationally between Indonesia and China. The Cheng Ho Mosque is one of the ethnic Chinese cultural identities in contemporary Indonesia. Currently, it is not only as a place of worship for Chinese Islam, but also as a religious tourism destination as well as new media to learn about Islamic Chinese cultures in Indonesia. In addition, Cheng Ho mosque is also beginning to be understood as the "new silk road", because it assumed that it has an important role in fostering a harmonious relationship between the Indonesian government and China. It can be seen from the establishment of Cheng Ho mosques in a number of regions in Indonesia. In this context, this article describes what the contributions and implications of the Cheng Ho mosque as the new silk road in fostering bilateral relations between Indonesia and China, especially in Islamic cultural identity.
\end{abstract}

Keywords: the Cheng Ho Mosque, Chinese muslim, Cultural Identity

\section{Introduction}

The Cheng Ho Mosque is a part of interesting topics on Chinese Muslim-Indonesian identities in Indonesia. Many researchers from all countries pay attention to this Mosque from different views. Hew Wai Weng in his doctoral research at ANU Canberra on "Chinese-style mosques in Indonesia" highlighted the unique architecture of the 
Cheng Ho Mosque in Surabaya, which has a Chinese style. ${ }^{1}$ Weng concluded that Chinese-style mosques in Indonesia have become a new phenomenon and trend for negotiating Chinese Muslims identities in Indonesia. ${ }^{2}$

In terms of political and social perspective, Akhmad Muzzaki concluded that the Cheng Ho Mosque played the role in negotiating Chinese Muslim identity and other identities in Post New Order Indonesia. Besides that, Muzzaki also discussed Cheng Hoo Mosque in the negotiation process, assimilation and acculturation of JavaneseChinese local cultures, and the relation between the mosque and the state, as well as mitigation and protection anti-Chinese stigma through the development of mosques. ${ }^{3}$

In other perspective, Anne Dickson noted that the role of Cheng Ho mosque as a symbol of unification for Indonesian Chinese is supported by the organization "PITI/ Persatuan Islam Tionghoa Indonesia" (Unity of Islamic Chinese in Indonesia). PITI has become a bridge between the Chinese muslim community with the Chinese (muslim or not muslim) and with the local Chinese community (nonChinese). ${ }^{4}$ While Zhuang Wubin a photographer in South East Asia countries presented the slides of his photography works for public on the portraits of Cheng Ho Mosque as well as the activities of Chinese Muslims in Indonesia. ${ }^{5}$

\footnotetext{
1 See Hew Wai Weng, "Negotiating Ethnicity and Religiosity: Chinese Muslim Identities in Post-New Order Indonesia" (Unpublished PhD thesis, Canberra: The Australian National University, 2011). Also see Hew Wai Weng, Translocal and Cosmopolitan Islam: Chinese-style Mosques in Indonesia and Malaysia (London: University of Oxford, Paper, 2012).

2 Hew Wai Weng. "Cosmopolitan Islam and Inclusive Chineseness: Chinese-style Mosques in Indonesia," in Chiara Formichi (ed.), "Religious Pluralism, State and Society in Asia" (London and New York: Routledge, 2013).

3 Akhmad Muzzaki "Negotiating Identity: The Cheng Hoo Mosque and The Ethnict Chinese Muslim in Post-Soeharto Indonesia," Chinese Southern Diaspora Studies, Volume 3, (2009). Also, Akhmad Muzzaki, "Cheng Hoo Mosque: assimilating Chinese culture, distancing it from the state" (London, UK: Crise Working Paper No.71, January 2010).

${ }^{4}$ Anne Dickson, A Chinese Indonesian Mosque's Outreach In The Reformasi Era (paper for the 17 Biennial Conference of the Asian Studies Association of Australia in Melbourne 1-3 July 2008).

5 Zhuang Wubin, Chinese Muslims in Indonesia, available at seasiaphotography.wordpress.com. Accessed on 2 September 2013.
} 
Saifullah Yusuf, East Java Deputy Governor, said that the Cheng Ho mosque is a symbol of peace among people of different faiths in the province. He explained that the unison of two cultures, Chinese and Islam, represents the unity. He noted that Cheng Ho mosque is a place of worship that symbolizes harmony, love and togetherness despite race or language. ${ }^{6}$

Different from the previous researches, this article focuses on the contribution of the Cheng Ho mosque to build a new perspective in the international relation between Indonesia and China. This paper tries to discuss on how the Cheng Ho mosque's role of social, cultural, educational and religious for the Chinese and non-Chinese in Indonesia as well as the contributions and implications of Cheng Ho mosque as the new silk road in fostering bilateral relations between Indonesia and China.

\section{Rethinking China, Islam and Indonesia}

The relationship between China and Indonesia in the past era has influenced Indonesia in many aspects. Azyumardi Azra from the State Islamic University in Jakarta said that the relationship between "Nusantara" or Indonesia and China has existed since pre-Islamic periode. The relationship left many important heritage and historical trail in the country. According to him, until now, many historians also have noted about history, religion, and culture of China that gave us important knowledge about how the relationship between China and Indonesia that occurred in the past needs to be improved in the future. ${ }^{7}$

Another expert, Leo Suryadinata from Singapore explained the history of Islam in Indonesia from the role of Zheng He. ${ }^{8}$ Edward L. Dreyer noted that Zheng He roles in the voyages were the spectacular voyages in the Early Ming Dynasty, 1405-1433. ${ }^{\text {According to }}$

\footnotetext{
${ }^{6}$ See report on "Chengho mosque, a symbol peace" at http://www.thejakartapost.com/news/2013/07/28/cheng-ho-mosque-a-symbol-peace.html. Accessed 8 November 2013 .

${ }^{7}$ See M. Ikshan Tanggok, et.al., Menghidupkan Kembali Jalur Sutra Baru: Format Baru Hubungan Islam Indonesia dan China (Jakarta: Gramedia Pustaka Utama, 2010).

${ }^{8}$ Leo Suryadinata (ed.), Laksamana Cheng Ho dan Asia Tenggara (Admiral Zheng He and Southeast Asia (Jakarta: Pustaka LP3ES, 2007). Also Leo Suryadinata, Southeast Asian Chinese: The Socio-Cultural Dimension (Singapore: Times Academic Press, 1995).

${ }^{9}$ Edward L. Dreyer. Zheng He: China and the Oceans in the Early Ming Dynasty, 1405-1433 (New York: Pearson Longman, 2007).
} 
Hembing Wijayakusuma, the real purpose of Cheng Ho's voyage in the country is to visit and spread the Islamic religion. ${ }^{10}$

In this context, Tan Ta Sen emphasized that today Islam in Indonesia cannot be separated from China contributions, especially Zheng He. ${ }^{11}$ In Tan's article, he cites that Zheng He's voyages took place within the larger context of "culture contact" in China and beyond. He illustrates the peaceful impact of culture contact, and demonstrates how such cultural influences not only led to the transmissions, conversions and transferences, involving inner Asian Muslims from China and Yunnan Muslims, as well as Chams, Javanese, Malays, Arabs and Indians, but also enabled many Chinese in the Malay world to retain non-Muslim cultural traits. ${ }^{12}$ Tan uses historical facts to strengthen the argument for the existence of the Third Wave, it is the Chinese Wave, in the spread of Islam in the Southeast Asian region; the two other major waves were the India-Gujarat Wave and the Middle East Wave. ${ }^{13}$

Besides Tan Ta Sen, Slamet Muljana also stated that Zheng He built Chinese Muslim communities firstly in Palembang, and then in San Fa (West Kalimantan). Subsequently, he founded similar communities along the shores of Java, the Malay Peninsula and the Philippines. Zheng He also propagated the Islamic faith according to the Hanafi school of thought. ${ }^{14}$

When visited Lautze Mosque in Jakarta, Din Syamsuddin, the Chairman of Muhammadiyah, said that one of the nearest religions in Chinese culture is Islam. ${ }^{15}$ According to him, the interaction has happened for a long time and contributed many things in this country. Din Syamsuddin added Haji Karim Oey, the top figure of Indonesian

10 Hembing Wijayakusuma, Muslim Tionghoa Cheng Ho (Jakarta: Yayasan Obor Indonesia, 2000).

${ }^{11}$ Tan Ta Sen. Cheng Ho and Islam in Southeast Asia (Singapore: Institute of Southeast Asian Studies, 2009).

12 See Choirul Mahfud "Lessons From Zheng He: Love of Peace and Multiculturalism" in Chia Lin Sien \& Sally K. Church (ed.), Zheng He \& the Afro-Asian World (Malaysia: PERZIM and the International Zheng He Society, 2012).

13 Ibid.

${ }^{14}$ Slamet Muljana. The Collapse of the Hindu-Javanese Kingdom and the Rise of Islamic States in the Archipelago (Yogyakarta: LKIS, 2005).

15 See http://www.republika.co.id/berita/video/bincang-tokoh/13/11/04/mvqioedin-agama-paling-dekat-dengan-budaya-cina-adalah-islam. Accessed 8 November 2013. 
Chinese Muslim, as the best friend of the former President Soekarno and Buya Hamka.

In another context, Tofan Hidayat said that Islam in China is not problem and not opposite to the Confucianism values. ${ }^{16}$ As known that there are five basic ideologies of Confucianism values which are very important for the Contemporary China, namely ren, yi, li, zhi, and $x i n$. The simply meaning, $r e n=$ benevolence/charity; $y i=$ righteousness; $l i=$ Propriety, $z h i=$ wisdom, and $x i n=$ trust. ${ }^{17}$

Sidharta Adhimulya also said the contribution of Zheng He or Cheng Ho is very meaningful in the world. ${ }^{18}$ Moreover, Rezza Maulana stated that the races of Cheesiness in Indonesia cannot be ignored. Historically, he argues, the Chinese people have been milling around in the archipelago for long time before enlightenment in the West. Therefore, until now the heritage of Chinese cultures also can be found in may areas in the archipelago. For examples, the Chinese language, architecture, the conception of the spiritual and the mundane, the names of streets, and various accessories of clothing and food names. ${ }^{19}$

Talking about China, Islam and Indonesia, it is very significant to talk about the Cheng Ho mosque as it has become the new media to learn about Chinese Islamic cultural identity as well as the new silk road for strengthening international relations between Indonesia and China, both on nowdays and the future. Moreover, Cheng Ho Mosque also has been a new icon of religious tourism on the Chinese Muslim communities in Southeast Asia, particularly in Indonesia. Also, Cheng Ho Mosque inspires Cheng Ho Mosques in other regions over Indonesia such as, in Surabaya, Jember, Pandaan Pasuruan, Malang, Purbalingga, Kalimantan, Jakarta and Palembang Jakabaring. ${ }^{20}$

\footnotetext{
${ }^{16}$ Interview with Tofan Hidayat, Surabaya, 18 September 2013.

${ }^{17}$ David Pong (ed.). Encyclopedia of Modern China (USA: Gale, Cengage Learning, 2009).

18 Interview with Sidharta Adhimulya, Surabaya, 8 September 2013.

${ }^{19}$ In Yogyakarta, there is a cake that called Bakpia. Now it becames favourite food of Yogyakarta. According to Rezza Maulana, the cake was first pioneered by a Chinese Indonesian Goei Gee Oe, who was living in the area Patuk, District Ngampilan, Yogyakarta. See Rezza Maulana. Tionghoa Muslim/Muslim Tionghoa (Yogyakarta: IMPULSE, 2010).

${ }^{20}$ See Choirul Mahfud, "Masjid Cheng Hoo sebagai Jalan Sutra Baru," Radar Surabaya (11 September 2013), p. 2.
} 


\section{The Potraits of Cheng Ho Mosque in Indonesia}

Generally, Cheng Ho Mosque in Indonesia is like a temple (house of worship of "Tri Dharma"). Cheng Ho Mosque is built firstly in Surabaya. The initiator of the construction of this mosque is HMY. Bambang Sujanto (Liu Min Yuan). In Surabaya, Cheng Ho Mosque is designed like mosque building in Beijing China, Niu Jie Mosque. Shortly, it can be said that the development of Cheng Ho mosque is a part of Islamic China's megatrend projects ${ }^{21}$ in the country.

Cheng Ho Mosque in Surabaya was inaugurated in 2002. HMY. Bambang Sujanto ${ }^{22}$ said that the name Cheng Ho Mosque tributes to the Admiral Cheng Ho or Zheng. The colours of the mosque are predominantly red, green and yellow. Its' building styles are assimilated to China, Arab and Javanese cultures. Cheng Ho Mosque is built with the concept without doors as a symbol of openness. It means that anyone from any ethnic is able to use the mosque for worship and other religious activities. Moreover, the mosque expected to bridge all the differences in Indonesia.

Until now, There are three mosques that similar to Cheng Ho Mosque built in several big cities in Indonesia such as the Cheng Ho Mosque in Palembang South Sumatra called Masjid Al Islam Muhammad Cheng $\mathrm{Ho}^{23}$, Cheng Ho Mosque in Pandaan Pasuruan East Java ${ }^{24}$, Cheng Ho Mosque in Jember East Java ${ }^{25}$, Cheng Ho

\footnotetext{
21 "China's Megatrends" is a term from Naisbitt. According to Naisbitt, China is not only undergoing fundamental changes but also creating an entirely new social and economic model—what the Naisbitts call a "vertical democracy"- that is changing the rules of global trade and challenging Western democracy as the only acceptable form of governing. See John \& Doris Naisbitt, China's Megatrends: 8 Pilar yang Membuat Dabsyat China (Jakarta: Gramedia Pustaka Utama, 2010).

22 Interview with HMY. Bambang Sujanto, Surabaya, 12 September 2013.

23 See http://id.wikipedia.org/wiki/Masjid Cheng_Ho Palembang. Accessed on 2 September 2013

${ }^{24}$ See "Cheng Ho Mosque in Pandaan, Pasuruan, East Java, (http://risalahmutiaratauhid.blogspot.com/2013/07/masjid-cheng-ho-surabaya-pandaan.html). Accessed on 2 September 2013.

${ }^{25}$ See "Cheng Ho mosque in Jember" at http://www.nu.or.id/a,public-m,dinamics,detail-ids,2-id,42465-lang,id-c,daerah-t,Masjid+Cheng+Hoo+Jember+Segera+Rampung-phpx. Accessed on 2 September 2013.
} 
Mosque in Banjarmasin South Kalimantan ${ }^{26}$ and Cheng Ho Mosque in Purbalingga Central Java ${ }^{27}$. All mosques are always visited by all visitors who generally come to worship, or simply enjoy the beauty of the architecture of the mosque building.

In addition, there are other mosques nuanced China such as the mosque of Muhammadiyah University Malang located in Malang. The mosque is not managed by the Chinese Muslim, but is managed by the university. Another is Kyai Bedjo mosque; its architectural style also is imitating Chinese style.

Seems that, the philosophy of the shape those mosques comes from the Islamic recommendation that is seeking knowledge throughout China as mentioned on the hadith of the prophet Muhammad SAW: "Please seek the knowledge as far as China". In this context, the Cheng Ho mosque is an inspiration for understanding Chinese Muslim cultures in Indonesia.

\section{The Role of Society, Culture, Education and Religion}

Since 1998, the Chinese Muslim identity is very significant and cannot be underestimated. The Chinese Muslims contributions can be detected from the systematization of Chinese Muslim organization movement called PITI (Indonesian Chinese Muslim Association) to the development of Cheng Ho mosque in all areas in Indonesia.

HMY. Bambang Sujanto, founder of Haji Muhammad Cheng Hoo Mosque Foundations in Surabaya, stated that Cheng Hoo mosque buildings in some areas are part of the mission of Chinese Muslims in this country for contributing, negotiating and strengthening their identities and roles like other civil society Islamic organizations. Until now, Sujanto added the mission is quite successful because it is always supported by all people. ${ }^{28}$

Specifically, Sujanto informed that Cheng Ho mosque in Surabaya is managed by the foundation of Haji Muhammad Cheng Hoo Indonesia in Surabaya and Indonesian Chinese Muslim Association

\footnotetext{
${ }^{26}$ See "The construction planning of Cheng Ho Mosque in Banjarmasin, South Kalimantan," at http://banjarmasin.tribunnews.com/2012/09/01/masjid-cheng-hodibangun-di-jalan-rk-ilir. Accessed on 1 September 2013.

${ }^{27}$ See "Architecture of Cheng Ho Mosque," at http://hardikadwihermawan.blogspot.com/2012/04/pesona-dan-gaya-arsitektur-masjid-cheng.html. Accessed on 2 September 2013.

${ }^{28}$ Interview with HMY. Bambang Sujanto, Surabaya, 12 September 2013.
} 
(PITI) in East Java. ${ }^{29}$ It known that PITI is not exclusive organization, but it is an inclusive Islamic Chinese organization in Indonesia. The inclusive characteristic of PITI can be seen from its vision to implement Islam for all humankind. ${ }^{30}$

The Cheng Ho mosque try to contribute to all people. Haryono Ong said that the Cheng Ho Mosque has been used for cultural, religious, and various social activities such as charities, social service and blood donors ${ }^{31}$. In education context, the Cheng Ho Mosque has teaching Chinese language teaching program; it also has a program of teaching-learning for children in the kindergarten, TK Istana Balita (ISBA). 32

The Pre-school 'ISBA' in the Cheng Ho mosque which has two classes of playgroup (A and B class) try to familiarize his students about 4 languages (Arabic, English, Chinese and Indonesian). ${ }^{33}$ All languages are designed and practiced to make kids more excited to learn. Generally, a teacher ISBA Diani Yudiwati said that the children do not complain to the multi-languages curriculum policy as the practice it in joyful learning by doing and playing. ${ }^{34}$

Furthermore, a few years ago, because of its uniqueness and all the roles, the Cheng Ho Mosque received an award from the Indonesian Record Museum (MURI) as one of the most unique mosque in Indonesia. Haryono Ong added that the mosque was awarded MURI as the first mosque uniquely name "Cheng Ho".35

\footnotetext{
${ }^{29}$ Interview with HMY. Bambang Sujanto, Surabaya, 12 September 2013.

${ }^{30}$ Choirul Mahfud. Manifesto Politik Tionghoa di Indonesia (Yogyakarta: Pustaka Pelajar, 2013), pp. 290-297.

${ }^{31}$ See "Praying besides traveling at Cheng Ho Mosque," at http://www.wego.co.id/berita/wisata-sekaligus-ibadah-di-masjid-cheng-ho-surabaya/. Accessed on 2 September 2013.

32 See http://istanabalita.blogspot.com/. Accessed on 2 September 2013.

${ }^{33}$ See http://istanabalita.blogspot.com/2009/08/rangsang-kreatifitas-balita-ajarkan.html. Accessed on 8 September 2013.

${ }^{34}$ Interview with Diani Yudiwati, Surabaya, 21 September 2013.

35 Interview with Haryono Ong, Surabaya, 21 September 2013.
} 


\section{The New Silk Road: The Cheng Ho Mosque's Contributions and Implications}

The new silk road is now become new topic for reminding the monumental "old" silk road. As known from several notes that historically, the "old" silk road was an important pathway for China's diplomatic relations and trade with the other countries from Asia, Africa, to Europe during the Han Dynasty. Today, the Chinese Muslims in Indonesia have initiation and important contribution to rebuild track the "new" silk road through the Cheng Hoo Mosque in Indonesia. It can be seen from how the role of the Cheng Ho mosques in is not only as a place of worship for Chinese muslim in the country, but also as a new media to learn about Islamic, Chinese and Indonesian cultures. Recently, Presiden Yudhoyono and President Xi Jinping from China make a new comprehensive strategic cooperation in all aspects, including in religious and Islamic cultural aspect. ${ }^{36}$ The purposes of the cooperation are for understanding and bettering the realtionship between the two countries. Presiden Yudhoyono said that Indonesia and China have similar dreams and hopes, but different ways to get them. In this context Presiden Yudhoyono cited Chinese wiseword "tong cu-wang $i$ meung" (different dreams in similar place) and "i cu-wang tong meung" (similar dreams in the different place). ${ }^{37}$

Besides that, The Minister of Religious Affairs Suryadhama Ali said that the governments of Indonesia and China have agreed to raise social and cultural relations between the two countries especially in Islamic relations. He added Islamic relations between the two countries have been going well and are expected to increase. ${ }^{38}$

Regarding this, M. Ikhsan Tanggok wrote a book on "Reviving New Silk Road: New Format Islamic Relations Indonesia and China ${ }^{39}$, it is one of the education cooperation products between the two countries. The book is relevant to understand the new silk road Indonesia-China relations. In this book Tanggok says that by understanding the contribution of Cheng Ho mosque, it can be concluded that Cheng Ho

\footnotetext{
36 See http://indonesian.cri.cn/201/2013/10/03/1s142384.htm. Accessed on 8 November 2013; Also see China Town Magarines, 73/VII (November 2013), pp. 12-17.

${ }^{37}$ China Town Magazines, 73/ VII (November 2013), p. 16.

${ }^{38}$ See http://www.antaranews.com/print/212895/. Accessed on 8 November 2013.

${ }^{39}$ See M. Ikshan Tanggok, et. al., Menghidupkan Kembali Jalur Sutra Baru: Format Baru Hubungan Islam Indonesia dan China (Jakarta: Gramedia Pustaka Utama, 2010).
} 
mosque is a new media for reviving new silk road of China-Indonesia relations.

Sujanto said that before building and developing the Cheng Ho mosque, many Chinese identities and cultures in Indonesia are unsupported by all people. But, after success in building Cheng Ho mosque in Surabaya, Sujanto added that many people start understanding and respecting about Chinese multi-cultures, religions and identities. ${ }^{40}$

Many events of understanding China-Indonesia identities and cultures were organized in the two countries. The daily newspaper Republika reported the Chinese Islamic Cultural Exhibition in Indonesia and China, which has been organized to strengthen the relationship between Indonesia and China. ${ }^{41}$ Interestingly, Fareed Zakaria noted that China in the present is different from in the past in all aspects, including in paying attention to the religions. Zakaria also said that China's progress today is also influenced by the Chinese people's belief in God. This is a surprise to some Western people who consider that Chinese do not believe in God. ${ }^{42}$

Chairman of the Islamic Association of China, Chen Guangyuan Hilaluddin said, the current existence of the Muslim community in China is highly developed. It is characterized by the number of imams who reached 40 thousand people. Even the number of mosques reached 35 thousand mosques. ${ }^{43}$

\footnotetext{
${ }^{40}$ Interview with HMY. Bambang Sujanto, Surabaya, 12 Agustus 2013.

41 See "Indonesia-China exhibitian," at http://www.republika.co.id/berita/duniaislam/islam-nusantara/10/07/21/125645-pameran-islam-cina-pererat-hubunganindonesia-cina. Accessed on 8 October 2013.
}

42 Citing a Pew survey in 2007, Fareed Zakaria describes a unique reality: "In the 2007 Pew survey, when asked whether one must believe in God to be moral, a comfortable majority of Americans (57 percent) said yes. In Japan and China, however, much larger majorities said no-in China, a whopping 72 percent! This is a striking and unusual divergence from the norm, even in Asia. The point is not that either country is immoral - in fact all hard evidence suggests quite the opposite- but rather that in neither country do people believe in God. This might shock many in the West, but for scholars of the subject, it is a well-known reality". See Fareed Zakaria, The PostAmerican World (London: Allen Lane, 2008).

43 See "Indonesia-China exhibitian," at http://www.republika.co.id/berita/duniaislam/islam-nusantara/10/07/21/125645-pameran-islam-cina-pererat-hubunganindonesia-cina. Accessed on 8 October 2013. 
On the same event, the Chairman of the Indonesian Ulama Council (MUI), KH Amidhan stated that Muslim cultural exhibition in China have also been held in Indonesia as one of the Indonesian Government's efforts to introduce Chinese culture to the muslim in Indonesia. Art displayed include Chinese calligraphy, the art of reading the Qur'an, photo exhibitions of the relationship between Indonesia and China, photographs of the development of Islamic culture in China and others. ${ }^{44}$

Besides that, the Cheng Ho mosque in Surabaya also has moment and agend of cleric exchange from Indonesia to China and also from China to Indonesia. The cleric and ulama from all the influenced Islamic organization leaders, such as Muhammadiyah, Nahdlatul Ulama and Indonesia Ulama Council (MUI) ${ }^{45}$, are always invited by Cheng Ho mosque to follow and participate to cleric exchange from Indonesia to China. It is expected that through these programs, many Indonesian Muslim leaders can help to understanding other people to respect identities and cultures of China and Chinese. ${ }^{46}$

Interestingly, the Cheng Ho mosque in Surabaya also makes a magazine named "Cheng Hoo" magazine. The magazine aims to help all people who want to know more information about the mosque and its contributions. Substantially, it contributes to the China-Indonesia cross-cultural understanding.

Former President Burhanudddin Jusuf Habibie said Muslims in Indonesia and China can work together and strengthen relations between the two countries. Habibie also said Indonesia and China have a long history which has affected the development of Islam in Indonesia. ${ }^{47} \mathrm{Habibie}$ stated that relation between Indonesia and China is long one rooted in culture. In the future, he said, Indonesia and China can continue to improve relations in various fields, not only for

\footnotetext{
${ }^{44}$ Ibid.

45 See Khoirun Niam. "The Discourse of Muslim Intellectuals and 'Ulama' in Indonesia: A Historical Overview," Journal of Indonesian Islam, Volume 04, Number 02 (December 2010): pp. 287-300.

${ }^{46}$ Interview with Liem Ou Yen, Surabaya, 12 Agustus 2012.

47 See report on "Indonesia-China can make good relations," at http://id.berita.yahoo.com/habibie-muslim-indonesia-china-dapat-pererat-hubungan-114503240.html. accessed on 8 November 2013.
} 
the benefit of both countries but also the region of peace and a better quality of life. ${ }^{48}$

Ali Karim Oe said that the presence of Chinese Muslims in Indonesia equal with the presesence of other Muslims in Indonesia. The establishment of the Lao Tse or Cheng Ho Mosque are expected to have positive impact to the relationship between Indonesia and China. He also added that by the presence of Chinese Muslims in Indonesia, hopefully, could further strengthen the relationship between the two countries in all aspects of life. ${ }^{49}$

In addition, the Cheng Ho mosques in Indonesia also contributed to appreciate differences of cultural identities in the country. This suits to C.Y. Hoon's conception in facing diversity in social life. ${ }^{50}$ Hoon ever gives "keywords" how to respond the diversity and differences in symbols of a multicultural society such as Indonesia. The "Keywords" are interethnic relations and interactions between symbol difference should not by way of "overcoming" or "away" differences, but to "live with", or "live through" the difference. "Overcome" and "away" means it will tend to be apathetic, even repressive and oppressive. While term "living with" means it will make someone keeps trying to know each other and doing dialogue. So did "live through" the symbol of the difference is not a challenge or obstacle, but it is an opportunity that can be used as the progress of society and the nation's capital.

In this context, Chinese and other cultures in this country can be viewed as social capital towards integration and appreciation for multicultural Indonesian identities. Social capital, as Robert D. Putnam $^{51}$ and Francis Fukuyama ${ }^{52}$ explained that there are at least two

\footnotetext{
48 Ibid.

${ }^{49}$ Ibid.

50 See for instance C.Y. Hoon, Chinese Identity in Post-Subarto Indonesia: Culture, Politics and Media (Brighton, UK: Sussex Academic Press, 2008).

${ }^{51}$ Robert D Putnam introduces the idea of social capital that "whereas physical capital refers to physical objects and human capital refers to the properties of individuals, social capital refers to connections among individuals-social networks and the norms of reciprocity and trustworthiness that arise from them. In that sense, Putnam said that social capital is closely related to what some have called "civic virtue." The difference is that "social capital" calls attention to the fact that civic virtue is most powerful when embedded in a sense network of reciprocal social relations. A society of many virtuous but isolated individuals is not necessarily rich in social capital". For more see Robert D. Putnam, Bowling Alone: The Collapse and Revival of American Community (New York: Simon and Schuster, 2000), p.19.
} 
things: trust and network. Networking is reinforced by the trust will be an imagined communities. ${ }^{53}$ In all aspects, the Cheng Ho mosques in Indonesia also have roles for fertilizing socio-cultural capital in the country.

\section{Conclusion}

The role of the Cheng Ho Mosque in Indonesia is very significant to be a new silk road, China-Indonesia relations. With the support of the leaders of Cheng Ho Mosque in several regions in Indonesia many cooperation in all aspects are more easily achieved. For examples, in the social, religious and cultural contexts, there has been an ulama exchange program which aims to share experiences and understanding of Islam in Indonesia and China. In education area established Chinese language teaching program.. The contribution and implications of Cheng Ho mosque development in Surabaya has inspired to all people in all regions in Indonesia even in Southeast Asia to establish a unique and distinctive mosque like Cheng Ho. For the better development of Cheng Ho Mosque in the country, the government and other communities need to support the Cheng Ho mosque development projects in some areas in Indonesia in order to celebrate Islamic cultural identity on the one hand and the other hand to celebrate Chinese multi-cultures in Indonesia. []

\footnotetext{
${ }^{52}$ Fukuyama wrote that "Trust is the expectation that arises within a community of regular, honest, and cooperative behavior, based on commonly shared norms, on the part of other members of that community ... Social capital is a capability that arises from the prevalence of trust in a society or in certain parts of it. It can be embodied in the smallest and most basic social group, the family, as well as the largest of all groups, the nation, and in all the other groups in between. Social capital differs from other forms of human capital insofar as it is usually created and transmitted through cultural mechanisms like religion, tradition, or historical habit". See more at Francis Fukuyama, Trust: Social Virtues and the Creation of Prosperity (Simon and Schuster, 1996), p.26.

53 "Imagined communities" is a concept coined by Benedict Anderson. Anderson said "an imagined community is different from an actual community because it is not based on everyday face-to-face interaction between its members. For example, Anderson believes that a nation is a socially constructed community, imagined by the people who perceive themselves as part of that group". See Benedict Anderson, Imagined Communities: Reflections on the Origin and Spread of Nationalism (London: Verso, 1983).
} 


\section{References}

\section{Books and Articles}

Anderson, Benedict. Imagined Communities: Reflections on the Origin and Spread of Nationalism. London: Verso, 1983.

Dreyer, Edward L. Zheng He: China and the Oceans in the Early Ming Dynasty, 1405-1433. New York: Pearson Longman, 2007.

Fukuyama, Francis. Trust: The Social Virtues and The Creation of Prosperity. New York: The Free Press, 1995.

Hew, W. W. Negotiating Ethnicity and Religiosity: Chinese Muslim Identities in Post-New Order Indonesia. Unpublished $\mathrm{PhD}$ thesis, Australian National University, 2011.

--------. Cosmopolitan Islam and Inclusive Chineseness: Chinese-style Mosques in Indonesia In Religious Pluralism, State and Society in Asia. London and New York: Routledge, 2013.

Hoon, C. Y. Chinese Identity in Post-Subarto Indonesia: Culture, Politics and Media. Brighton, UK: Sussex Academic Press, 2008.

Mahfud, Choirul. Manifesto Politik Tionghoa di Indonesia. Yogyakarta: Pustaka Pelajar, 2013.

---------. "Lessons From Zheng He: Love of Peace and Multiculturalism." Chia Lin Sien \& Sally K Church (eds). Zheng $\mathrm{He}$ \& the Afro-Asian World. Malaysia: PERZIM and the International Zheng He Society in Singapore, 2012.

Maulana, Rezza. Tionghoa Muslim/Muslim Tionghoa. Yogyakarta: IMPULSE, 2010.

Muzzaki, Akhmad, "Negotiating Identity: The Cheng Hoo Mosque and The Ethnict Chinese Muslim in Post-Soeharto Indonesia." Chinese Southern Diaspora Studies, Volume 3, 2009.

-------. Cheng Hoo Mosque: assimilating Chinese culture, distancing it from the state. London, UK: Crise Working Paper No.71, January 2010.

Naisbitt, John \& Doris. China's Megatrends: 8 Pilar yang Membuat Dabsyat China. Jakarta: Gramedia Pustaka Utama, 2010.

Niam, Khoirun. "The Discourse of Muslim Intellectuals and 'Ulama' in Indonesia: A Historical Overview." Journal of Indonesian Islam, Volume 04, Number 02, December 2010. 
Pong, David (ed.). Encyclopedia of Modern China. USA: Gale, Cengage Learning, 2009.

Putnam, Robert D. Bowling Alone: The Collapse and Revival of American Community. New York: Simon and Schuster, 2000.

Suryadinata, Leo. Southeast Asian Chinese: The Socio-Cultural Dimension. Singapore: Times Academic Press, 1995.

-. Laksamana Cheng Ho dan Asia Tenggara. Jakarta: Pustaka LP3ES, 2007.

Tanggok, M. Ikhsan. Menghidupkan Kembali Jalur Sutra Baru Format Baru Hubungan Islam Indonesia dan China. Jakarta: Gramedia Pustaka Utama, 2010.

Tan Ta Sen. Cheng Ho and Islam in Southeast Asia. Singapore: Institute of Southeast Asian Studies, 2009.

Wijayakusuma, Hembing. Muslim Tionghoa Cheng Ho. Jakarta: Yayasan Obor Indonesia, 2000.

\section{Electronic Sources}

Seasiaphotography.wordpress.com. Accessed on 2 September 2013.

http://id.berita.yahoo.com/habibie-muslim-indonesia-china-dapatpererat-hubungan-114503240.html. Accessed on 8 November 2013.

http://www.republika.co.id/berita/dunia-islam/islam-nusantara/10/07/21/125645-pameran-islam-cina-pererat-hubungan-indonesia-cina. Accessed on 8 October 2013.

http://www.antaranews.com/print/212895/. Accessed on 8 November 2013.

http://indonesian.cri.cn/201/2013/10/03/1s142384.htm. Accessed on 8 November 2013.

http://hardikadwihermawan.blogspot.com/2012/04/pesona-dangava-arsitektur-masjid-cheng.html. Accessed on 2 September 2013.

http://banjarmasin.tribunnews.com/2012/09/01/masjid-cheng-hodibangun-di-jalan-rk-ilir. Accessed on 1 September 2013. 
http://www.nu.or.id/a,public-m, dinamic-s, detail-ids,2-id,42465-langid-c,daerah-t,Masjid+Cheng+Hoo+Jember+Segera+Rampung.phpx. Accessed on 2 September 2013.

http://risalahmutiaratauhid.blogspot.com/2013/07/masjid-cheng-hosurabaya-pandaan.html. Accessed on 2 September 2013.

http://www.wego.co.id/berita/wisata-sekaligus-ibadah-di-masjidcheng-ho-surabaya/. Accessed on 2 September 2013.

http://regional.kompas.com/read/2011/07/24/2119416/Masjid.Che ng.Hoo.Simbol.Keterbukaan. Accessed on 1 September 2013.

http://www.republika.co.id/berita/video/bincang-tokoh/13/11/04/mvqioe-din-agama-paling-dekat-dengan-budaya-cina-adalahislam. Accessed on 8 November 2013.

http://www.thejakartapost.com/news/2013/07/28/cheng-homosque-a-symbol-peace.html. Accessed on 8 November 2013.

\section{Interviews}

Interview with HMY. Bambang Sujanto, Surabaya, 12 September 2013.

Interview with Sidharta Adhimulya, Surabaya, 8 September 2013.

Interview with Liem Ou Yen, Surabaya, 12 Agustus 2012.

Interview with Tofan Hidayat, Surabaya, 18 September 2013.

Interview with Haryono Ong, Surabaya, 21 September 2013. 